\title{
Effects of Hurricane Hugo (1989) on a coral reef in St. John, USVI
}

\author{
Caroline S. Rogers, Larry N. McLain, Craig R. Tobias
}

Virgin Islands National Park, PO Box 710, St. John, U.S. Virgin Islands 00830

\begin{abstract}
In January 1989, a long-term study site was established on a coral reef off the south coast of St. John, U.S. Virgin Islands. Five $20 \mathrm{~m}$ transects were installed at depths of ca 11 to $13 \mathrm{~m}$. Hurricane Hugo struck St. John on September 17 and 18, 1989. Analysis of quantitative data collected before and after the storm allowed documentation of the effects of this powerful storm on coral community structure. The total living cover by scleractinians, including the dominant species, Montastrea annularis, decreased significantly. The amount of substrate available for colonization increased. Cover by macroscopic algae increased dramatically after the storm, later decreased, and then rose again 1 yr later. In spite of the reduction in live cover by the dominant coral species, neither diversity $\left(\mathrm{H}^{\prime}\right)$ nor evenness ( $\left.\mathrm{J}^{\prime}\right)$ increased. Topographical complexity, estimated from calculations of spatial indices, did not decrease along the transects as a result of the storm. No measurable recovery of the live corals has occurred in the 12 mo following the initial post-storm survey.
\end{abstract}

\section{INTRODUCTION}

Observations of the effects of major storms on Caribbean coral reefs in the last $12 \mathrm{yr}$ reveal certain patterns of response (Woodley et al. 1981, Porter et al 1981, Rogers et al. 1982, 1983, Kjerfve et al. 1986) Damage results from the physical force of hurricaneinduced waves, sand-blasting of live tissue, abrasion from impact with dislodged coral fragments, and smothering or burial of organisms in sand transported by storm seas. Damage is variable or 'patchy' on several scales (e.g. Woodley et al. 1981). Generally, it is more severe in shallower water (Endean 1976, Porter et al. 1981, Woodley et al. 1981, Rogers et al. 1982, but see Dollar 1982). The composition of the hard coral community in a particular reef zone (itself partially a function of storm frequency and intensity) will influence the amount and type of damage that is inflicted For example, branching coral species tend to suffer more destruction than head colonies (e.g. Glynn et al 1964, Stoddart 1974, Porter et al. 1981, Woodley et al 1981). The amount and type of destruction which a reef sustains during a major storm will partly be a reflection of how much time has passed since a comparable storm occurred (Woodley et al. 1981). Algae are the first obvious colonizers of new substrate created by storms (e.g. Woodley et al. 1981, Rogers et al 1982, Walsh 1983).
The 1988 and 1989 seasons witnessed 5 category 4/5 hurricanes in the Caribbean (including Gibert and Hugo), the largest number of such powerful storms since the 1960 and 1961 seasons which had a total of 6 (Case \& Mayfield 1990). Above-normal rainfall over Africa in the summer of 1989 (Gray 1990) may have been correlated with the intensity of the waves which formed off Cape Verde and developed into hurricanes (Avila 1990).

Since 1900, 11 hurricanes and numerous tropical storms have passed within 60 nautical miles of St. John, St. Thomas, and St. Croix, the United States Virgin Islands (USVI) (Neumann et al. 1978). Recent tropical storms and hurricanes which have affected USVI coral reefs (prior to Hugo) include Tropical Storm Klaus (1984), Hurricane David (1979), Tropical Storm Frederic (1979), and Hurricane Gilbert (1988), with Klaus and David probably the most destructive. Tropical storms which pass directly over or near the islands can be more devastating than hurricanes which move by at a great distance.

The eye of Hurricane Hugo, one of the strongest storms in the Caribbean this century, passed directly over St. Croix, USVI, on September 17 and 18, 1989. Hugo devastated portions of coral reefs and seagrass beds in St. Croix, and in St. Thomas and St. John, ca $56 \mathrm{~km}$ to the north (Bythell et al. 1991, Gladfelter et al. 1991). 
In January 1989, we established a long-term study site off Yawzi Point, which separates Little and Great Lameshur Bays on the south coast of St. John (Fig. 1). Consequently, we had the opportunity to collect quantitative data prior to and after Hurricane Hugo. This paper presents the effects of this powerful storm on the structure of the Yawzi Point coral reef, including live coral cover and diversity.

\section{Characteristics of Hurricane Hugo}

Hurricane Hugo formed off the west coast of Africa and moved in a predominately westerly direction towards the USVI (Fig. 2). On September 15, 1989, $2 \mathrm{~d}$ before the storm hit the USVI, a reconnaissance airplane hundreds of miles east of the islands recorded a central pressure of $918 \mathrm{mb}$, a wind speed of $306 \mathrm{~km} \mathrm{~h}^{-1}$ at an altitude of $500 \mathrm{~m}$ and a surface wind of $259 \mathrm{~km}$ $\mathrm{h}^{-1}$ (Case \& Mayfield 1990). Hugo was a category 5 hurricane before it hit St. Croix. An estimated maximum surface wind of $223 \mathrm{~km} \mathrm{~h}^{-1}$ was reported as the eye passed over St. Croix on the night of September 17 to 18 . The eye of the storm had a forward speed of only $14 \mathrm{~km} \mathrm{~h}^{-1}$ when moving over the island (Case \& Mayfield 1990), and the hurricane battered the USVI for over $12 \mathrm{~h}$. Rainfall totals for September 17 to 19 at 5 sites on St. John ranged from $143 \mathrm{~mm}$ to $245 \mathrm{~mm}$ (NOAA Climatological Data).

\section{Selection of long-term study site}

In 1988, the National Park Service initiated a longterm coral reef assessment program for Virgin Islands National Park on St. John. A primary objective of this program is to establish permanent long-term sites on coral reefs around the island. Virgin Islands National Park is an international biosphere reserve, one of over 285 reserves designated by UNESCO in over 110 countries. The ecosystems in biosphere reserves are intended to serve as points of comparison with similar systems in unprotected areas which are presumably more degraded or more likely to become so. We intentionally selected a site which receives little impact from human activities.

The site is a coral reef off Yawzi Point, a rocky point which separates Little and Great Lameshur Bays, on the southern shore of St. John (Fig. 1). The hydrocoral Millepora spp. and other encrusting corals grow on boulders fringing this point. A diverse reef slopes rapidly to about 7.6 to $9.1 \mathrm{~m}$ where it begins to level out. Further seaward, the reef slopes abruptly from about $12 \mathrm{~m}$ to $13.7 \mathrm{~m}$ terminating in a well-defined sand channel which separates the base of the reef from a seagrass bed.

\section{METHODS}

In January 1989, we established five $20 \mathrm{~m}$ transects in 10.7 to $12.7 \mathrm{~m}$ off Yawzi Point. We chose a transect length of $20 \mathrm{~m}$ after surveying preliminary transects which indicated a leveling off in the number of hard coral species found after $14 \mathrm{~m}$. The transects lie along the $12 \mathrm{~m}$ depth contour within an area of about $1800 \mathrm{~m}^{2}$ and were randomly selected. Each of the transects was delineated with 3 survey stakes, one at each end and one in the middle. The stakes are copper-covered steel survey markers with bronze heads. Using a pneumatic drill powered by the compressed air of a Scuba tank, a diver drilled a hole into the substrate and then inserted

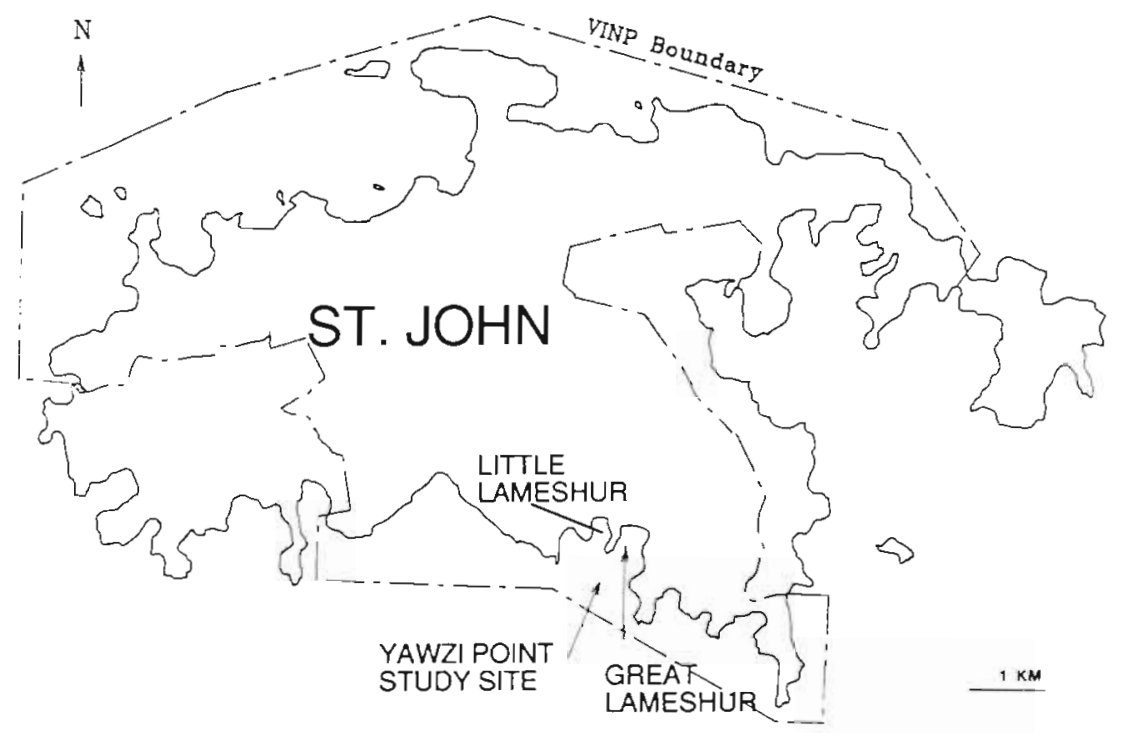

Fig. 1. Map of St. John showing study site off Yawzi Pt. 
Fig. 2. Path of Hurricane Hugo in the Carib-

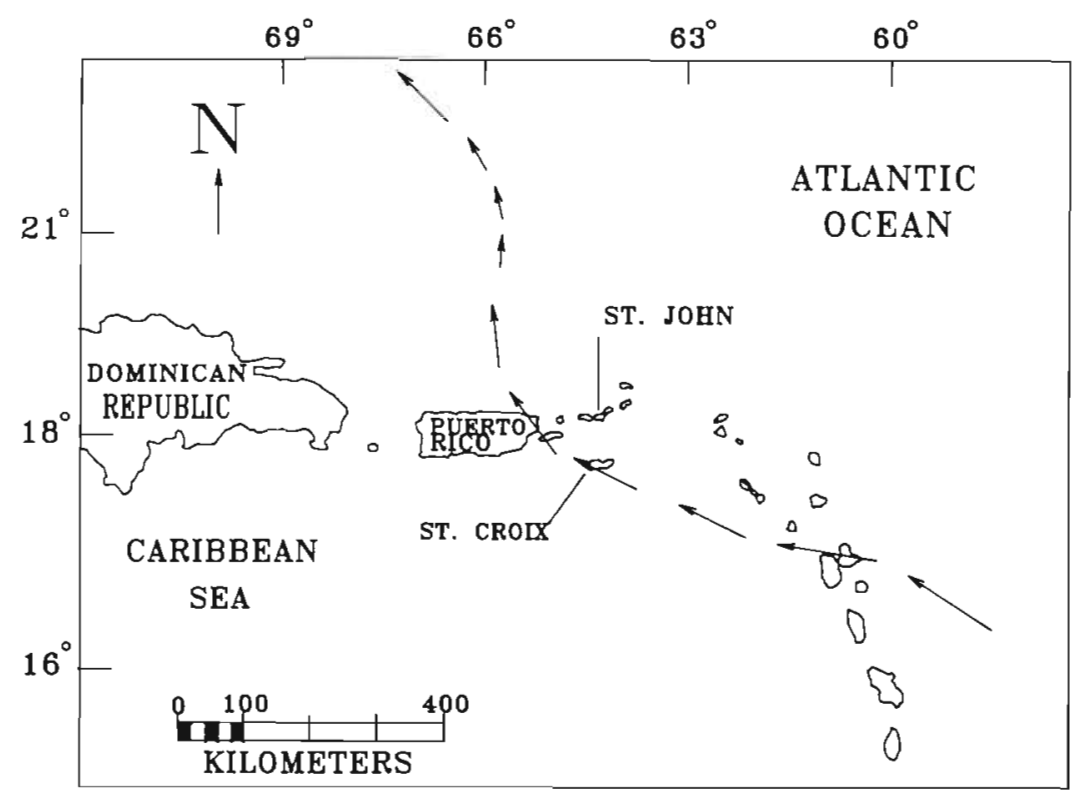

the survey stake into the hole. Underwater epoxy was used to cement each stake into place. Numbers were stamped in to the heads of the survey stakes after placement. Thirteen of the 15 markers were relocated in their original positions after the hurricane, and we were able to reconstruct the locations of all transects.

Transects were surveyed with Scuba using a linear chain transect method, a modification of methods originally used by Loya \& Slobodkin (1971), Loya (1972) and Porter (1972). It takes about $3 \mathrm{~h}$ (2 dives, each $1.5 \mathrm{~h}$ long) to survey one $20 \mathrm{~m}$ transect. The end of a fiberglass measuring tape is secured to a survey stake at the beginning of a transect and stretched $10 \mathrm{~m}$ to the middle survey stake at the height of the highest feature along the transect. A light-weight chain is placed directly beneath the measuring tape, following the bottom contour as closely as possible. The diver records the number of chain links which cover each living and non-living reef component. From these measurements, the percent cover of each component can be calculated. (The tape is then moved and resecured to the next $10 \mathrm{~m}$ of the transect, and so on.) The ratio of the number of centimeters of chain (converted from the number of $1.3 \mathrm{~cm}$ links) to the number of centimeters of measuring tape provides an indicator of the topographical relief or 'the spatial index' (see also Risk 1972, Luckhurst \& Luckhurst 1978).

Diversity and evenness of hard coral species (scleractinians and the hydrozoan Millepora spp.) for each sampling period were calculated based on combined data from all 5 transects. We used the transect data to calculate diversity (Shannon \& Weaver 1949) as follows:

$$
H^{\prime}=-\Sigma p_{i} \ln p_{i}
$$

where $p_{i}=n_{1} / N$, in which $N=$ total number of centimeters (individuals) of all species under the line, and $n_{2}=$ the number of centimeters of species ' $i$ ' under the line. [Pielou (1977) notes that this index underestimates the actual value of $\mathrm{H}^{\prime}$ for the entire community. Here our interest was in comparing indices for the same group of transects over time.]

Evenness was calculated as $\mathrm{J}^{\prime}=\mathrm{H}^{\prime} / \mathrm{H}_{\text {max }}^{\prime}$ (Pielou 1966) and represents the diversity of the combined transect data divided by the diversity which would occur if all of the species present were distributed equally. A value of 1.00 represents maximum evenness.

The linear transect method is effective in documenting relative changes in mean values for major structural components (e.g. total live coral cover, cover by the most abundant coral species) for all transects per sampling period. It does not provide accurate data on changes in absolute abundance of benthic components, shifts in number of species, or cover by the less abundant hard coral species. It is not possible to position the chain in exactly the same location each time. Also, the total number of centimeters of cover by all components in a transect can vary even in the absence of major storms or other stresses because of shifts in spatial arrangement (Bak \& Luckhurst 1980). Therefore, it is necessary to look at relative (not absolute) changes in percent cover.

Transects were surveyed in January and June/July 1989; and then, following the hurricane, in November 1989, and March, August, and November/December 1990 .

When repeated measures analysis of variance (ANOVA) indicated a significant difference in means, 
the Bonferroni Multiple Comparison Test (Miller 1985) was used to determine which means differed significantly. All percentage data were transformed (arcsine) prior to analyses (Sokal \& Rohlf 1969).

\section{RESULTS}

\section{Characteristics of the site prior to the hurricane}

Thirty-three hard coral species were observed in the study area, with 23 of these represented in the transects. Montastrea annularis was by far the most abundant coral species. Siderastrea siderea and Diploria labyrinthiformis were also relatively abundant. The branching corals Acropora palmata and A. cervicornis were not present here.

\section{Effects of the hurricane}

During the passage of Hurricane Hugo, powerful storm seas fragmented and overturned coral colonies. Waves hurled fragments or entire colonies of coral into other colonies leaving visible impact scars. Coral rubble collected in large piles in sand channels and other depressions in the reef. Damage was patchy, with some portions of the reef exhibiting more destruction than others. While some pillar corals Dendrogyra cylindrus remained intact, branches had been sheared off most colonies.

At other sites around St. John, the storm surge transported loads of sediment and buried coral and gorgonian colonies. Off Yawzi Point, however, smothering by sediments was not observed. Water quality was poor due to turbidity associated with rainfall during and after the storm and suspension of reef sediments. However, the turbid conditions probably did not persist long enough to have serious deleterious effects on the reef organisms.

Some gorgonians were found at our study site lying in the sand with their holdfasts still attached to broken pieces of limestone rubble. Hundreds of gorgonians washed up on the beach in Great Lameshur Bay.

As a result of the storm, the average percent of living coral cover decreased significantly, from about $20 \%$ to about $12 \%$ (Fig. 3, Table 1 ). This represents a percentage change in living coral of about $40 \%$. There has been no significant increase in the amount of live coral in the 12 mo following the November, post-storm, survey. The only conspicuous recovery has been the healing of some coral scars.

Montastrea annularis was the dominant coral at the study site prior to the storm, comprising 18 to $50 \%$ (mean $=39 \%$ ) of the live coral in the transects. After the storm, this species remained the most abundant, comprising 29 to $61 \%$ (mean $=39 \%$ ) of the live coral remaining in the transects. $M$. annularis contributed a significantly higher percent of the total cover (nonliving and living) in the transects before the storm than after the storm (Fig. 4, Table 2).

Following the hurricane, there was a dramatic increase in cover by macroscopic algae, primarily the red Liagora spp. and the brown Dictyota spp. (Fig. 5 , Table 3). Liagora spp. was not conspicuously abundant on the reef by March, and most of the remaining

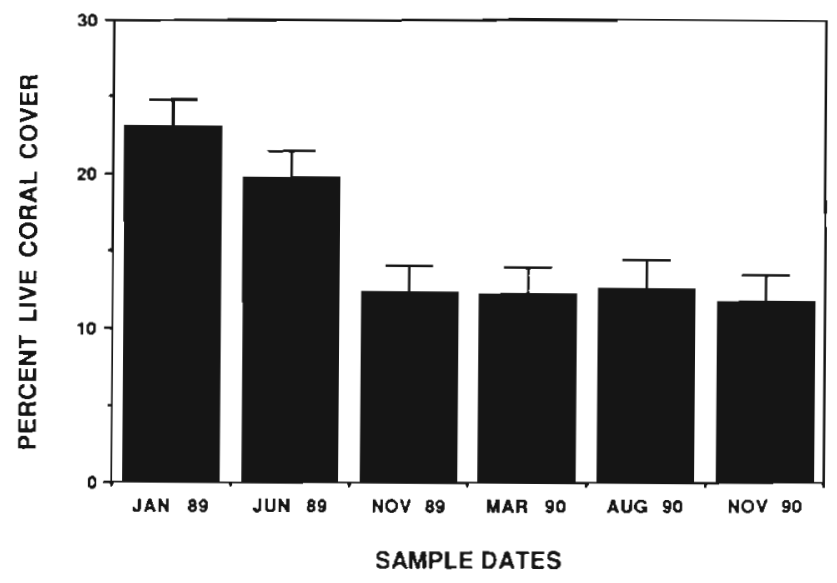

Fig. 3. Mean percent of live coral cover per sample period for all transects. Line above each bar represents one standard error $(n=5)$

Table 1. Results of repeated measures ANOVA comparing percent live coral cover among sample dates. Underlined means are not significantly different

\begin{tabular}{|c|c|c|c|c|c|c|}
\hline Source & SS & df & MS & $F$ & $\mathrm{p}$ & \\
\hline Among sample dates & 0.061 & 5 & 0.012 & 19.95 & $<0.001$ & \\
\hline Within sample dates & 0.012 & 20 & 0.001 & & & \\
\hline \multicolumn{7}{|c|}{ Bonferroni multiple comparisons: } \\
\hline Sample date & $\operatorname{Jan} 89$ & Jun 89 & Nov 89 & Mar 90 & Aug 90 & Nov 90 \\
\hline Percent cover & 23.1 & 19.8 & 12.3 & 12.2 & 12.6 & 11.7 \\
\hline
\end{tabular}




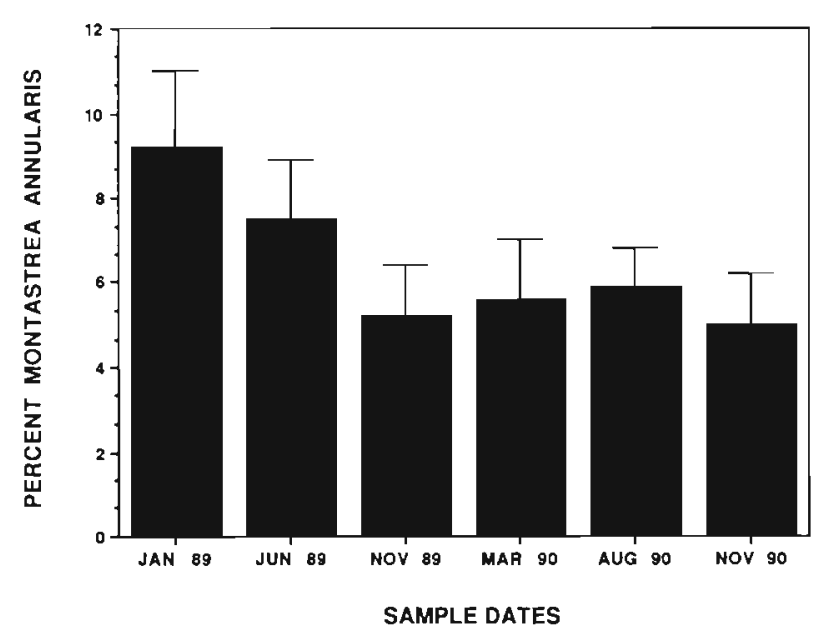

Fig. 4. Mean percent of Montastrea annularis per sample period for all transects. Line above each bar represents one standard error $(\mathrm{n}=5)$

macroalgae were Dictyota spp. Macroscopic algal cover had fallen to pre-storm levels by March and did not rise again until November 1990. Percent cover by macroscopic algae in November 1989, following the hurricane, and one year later did not differ significantly (Table 3).

To examine changes in the amount of substrate available for colonization, we combined the data for rubble, pavement, and dead coral. (We included values for substrate with macroalgae as well.) The amount of substrate increased significantly following the hurricane (Fig. 6, Table 4).

Looking at mean values for all transects per sampling period provided an indication of changes in the relative amount of cover attributable to (1) all live hard corals; (2) the dominant species, Montastrea annularis (3) macroscopic algae; and (4) substrate. The effects of Hurricane Hugo on these reef components are summarized in Table 5 which presents the results of repeated measures ANOVA before and after the storm.

Mean diversity $\left(\mathrm{H}^{\prime}\right)$ for all transects combined was $2.13(\mathrm{SD}=0.014)$ before and $1.94(\mathrm{SD}=0.057)$ after the storm. Corresponding values for evenness were 0.70 $(\mathrm{SD}=0.021)$ and $0.69(\mathrm{SD}=0.036)$.

No statistically significant differences in spatial indices for the transects were found (Table 6). One would expect a decrease in topographical relief following a destructive storm, particularly on reefs dominated by branching species such as Acropora palmata. However, it is theoretically possible that topographical relief could increase after a storm if coral fragments and colonies were transported into the transects or if colonies in the transects split into several fragments.

\section{DISCUSSION}

The variable or 'patchy' nature of damage from hurricanes noted in other studies was observed at our study site off Yawzi Point. The patchiness was evident over the entire reef as well as within study transects. Patchiness reflects the differential susceptibility of reef organisms to physical damage (Woodley et al. 1981). It

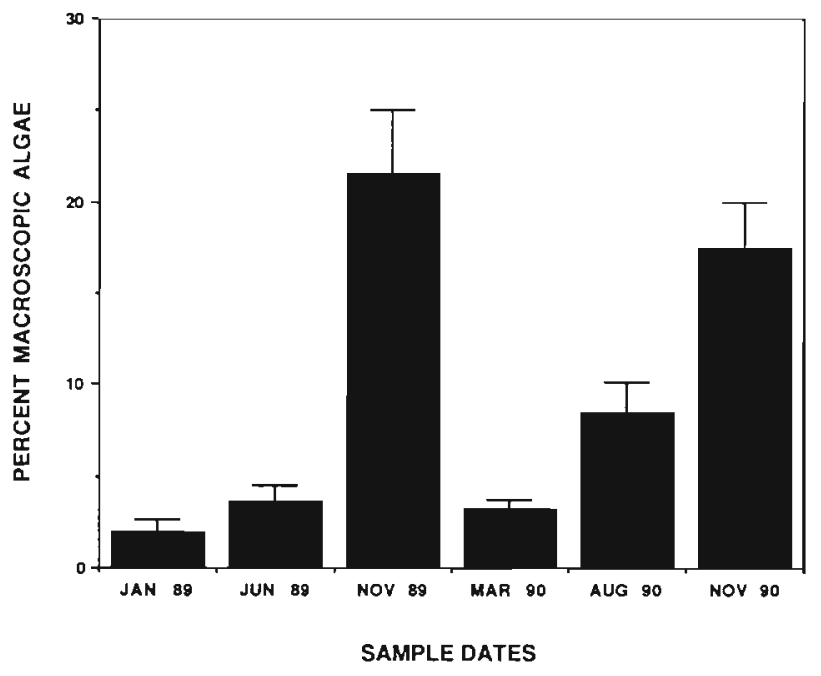

Fig. 5. Mean percent of cover by macroscopic algae per sample period for all transects. Line above each bar represents one standard error $(n=5)$

Table 2. Results of repeated measures ANOVA comparing live cover by Montastrea annularis among sample dates. Underlined means are not significantly different

\begin{tabular}{|c|c|c|c|c|c|c|}
\hline Source & SS & df & MS & $F$ & $\mathrm{p}$ & \\
\hline Among sannple dates & 0.007 & 5 & 0.001 & 5.70 & 0.002 & \\
\hline Within sample dates & 0.005 & 20 & 0.000 & & & \\
\hline \multicolumn{7}{|c|}{ Bonferroni multiple comparisons: } \\
\hline Sample date & Jan 89 & Jun 89 & Nov 89 & Mar 90 & Aug 90 & Nov 90 \\
\hline Percent cover & 9.2 & 7.5 & 5.2 & 5.6 & 5.9 & 5.0 \\
\hline
\end{tabular}


Table 3. Results of repeated measures ANOVA comparing cover by macroscopic algae among sample dates. Underlined means are not significantly different

\begin{tabular}{|c|c|c|c|c|c|c|}
\hline Source & SS & $\mathrm{df}$ & MS & $F$ & $\mathrm{p}$ & \\
\hline Among sample dates & 0.175 & 5 & 0.035 & 19.43 & $<0.001$ & \\
\hline Within sample dates & 0.036 & 20 & 0.002 & & & \\
\hline \multicolumn{7}{|c|}{ Bonferroni multiple comparisons: } \\
\hline Sample date & Jan 89 & Jun 89 & Nov 89 & Mar 90 & Aug 90 & Nov 90 \\
\hline Percent cover & 1.9 & 3.6 & 21.5 & 3.2 & 8.5 & 17.4 \\
\hline
\end{tabular}

also is a function of differences in reef depth and structure. Kjerfve et al. (1986) demonstrated that the bathymetry and topography of a particular reef area (e.g. its depth, its slope) along with its community structure influence the impact of storm seas (see also Dollar 1982). Using computer simulation, they found that the incident wave power during Hurricane Allen (1980) varied by a factor of 7 along a $3 \mathrm{~km}$ section of the forereef of Discovery Bay, Jamaica, because of differences in local bathymetry. The significant wave height at a particular time varied by a factor of 2.6 because of wave refraction.

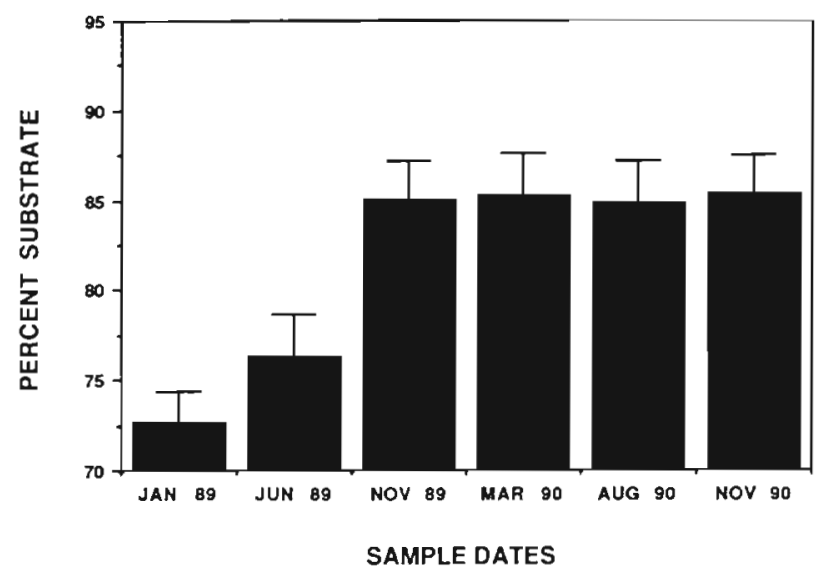

Fig. 6. Mean percent of substrate per sample period for all transects. Line above each bar represents one standard error $(\mathrm{n}=5)$

\section{Recovery}

To our knowledge, no one has quantitatively and comprehensively documented the full recovery of a coral reef following a major natural or human disturbance. Complete recovery to pre-disturbance conditions implies restoration of the same community structure and function, that is, recovery of all organisms on the reef and natural processes such as nutrient cycling. Documentation of total recovery would clearly be difficult and the few studies available on reef recovery focus mostly on hard corals (Stoddart 1963, 1969, 1974, Shinn 1972, Connell 1973, 1976, 1978, Grigg \& Maragos 1974, Rogers et al. 1982). For hard coral populations, recovery would entail restoration of percent cover, species diversity (evenness and richness), species similarity, and colony size distribution.

Recovery of hard coral populations takes place through (1) settlement, survival and growth of sexually produced coral recruits, (2) healing and regeneration of damaged colonies, and (3) growth of coral fragments (e.g. Connell 1973, 1976, 1978, Endean 1976, Loya 1976, Highsmith et al. 1980, Pearson 1981, Highsmith 1982). Recovery will clearly be impeded if (1) the substrate for settlement has been altered, (2) grazing is reduced, and (3) disturbance recurs or continues. Coral settlement will be hindered if the substrate has been modified by sediment deposition or, in severe cases, by physical planing which reduces the structural relief of the substrate. Rough substrate appears to facilitate

Table 4. Results of repeated measures ANOVA comparing cover by substrate among sample dates. Underlned means are not significantly different

\begin{tabular}{|c|c|c|c|c|c|c|}
\hline Source & SS & $\mathrm{df}$ & MS & $F$ & $\mathrm{p}$ & \\
\hline Among sample dates & 0.228 & 5 & 0.046 & 27.09 & $<0.001$ & \\
\hline Within sample dates & 0.034 & 20 & 0.002 & & & \\
\hline \multicolumn{7}{|c|}{ Bonferroni multiple comparisons: } \\
\hline Sample date & Jan 89 & Jun 89 & Nov 89 & Mar 90 & Aug 90 & Nov 90 \\
\hline Percent cover & 72.7 & 76.3 & 85.1 & 85.3 & 84.8 & 85.4 \\
\hline
\end{tabular}


Table 5. Comparisons of reef components before and after Hurricane Hugo. Means are followed by standard deviations in parentheses

\begin{tabular}{|c|c|c|c|c|}
\hline Reef components & Before & After & $F$ & $\mathrm{p}$ \\
\hline Live coral cover & $21.45(2.33)$ & $12.2 \quad(0.37)$ & 84.88 & $0.001 \cdots$ \\
\hline Montastrea annularis & $8.35(1.20)$ & $5.42(0.40)$ & 14.39 & $0.019^{\circ}$ \\
\hline Macroscopic algae & $2.75(1.20)$ & $12.65(8.31)$ & 34.89 & $0.004 \cdots$ \\
\hline Substrate & $74.5 \quad(2.55)$ & $85.15(0.27)$ & 89.31 & $0.001 \cdots$ \\
\hline
\end{tabular}

Table 6. Results of repeated measures ANOVA comparing spatial indices among sample dates. No means were significantly different

\begin{tabular}{|lccccc|}
\hline Source & SS & df & MS & $F$ & p \\
\hline Among sample dates & 0.231 & 5 & 0.046 & 1.95 & 0.130 \\
Within sample dates & 0.473 & 20 & 0.024 & & Mar 90 \\
Sample date & Jan 89 & Jun 89 & Nov 89 & Aug 90 & Nov 90 \\
Percent cover & 1.7 & 1.9 & 1.7 & 1.7 & 1.7 \\
\hline
\end{tabular}

coral settlement (Birkeland 1977, Brock 1979). Some evidence exists that corals settle preferentially on crustose corallines (Birkeland 1977, Brock 1979). If grazing is not intense enough, fleshy macroscopic algae dominate and corals do not settle. If the disturbance decreases the number of grazing organisms, recovery of the reef community will take longer (Pearson 1981).

Even in the absence of major storms, recovery will be delayed and additional damage may occur if loose coral fragments, detached boulders, and rubble are tossed around in strong currents. In cases where the actual framework of the reef structure has been altered, re-establishment of the pre-disturbance topography may never occur. Topographical relief at our study site as estimated by spatial indices from line transects did not change significantly as a result of the storm. Similarly, Rogers et al. (1983) noted little change in spatial indices for reef transects dominated by massive corals following 2 storms in 1979. Hurricane Hugo smashed branching corals (primarily Acropora palmata) in shallow, near-shore reef zones off St. John, but no estimates of changes in topographical relief are available. Presumably, reef zones dominated by branching species will exhibit greater changes than those where the 3 dimensional structure of the reef is mostly attributable to head corals.

The rate of recovery to pre-storm conditions will be influenced by the morphological and life-history characteristics of the dominant species and the nature of the damage the species sustained. The effects of storms on the dominant hard coral species has been documented for several different sites. In 1980, Hurricane Allen devastated the Discovery Bay Reef in Jamaica causing the greatest mortality among the most abundant branching species, Acropora palmata and $A$. cervicornis (e.g. Porter et al. 1981, Woodley et al. 1981, Knowlton et al. 1990).

Rogers et al. (1983) observed damage to shallow reefs off St. Thomas from Hurricane David which passed $268 \mathrm{~km}$ to the south of the USVI in 1979. They reported significant decreases in the amount of living coral on 2 reefs but no significant decrease in cover by the most abundant coral species, Montastrea annularis and Porites porites. Tropical Storm Klaus (1984) caused a statistically significant decrease in the mean percent of live coral from 26 to 21 at Fish Bay, St. John (Rogers \& Zullo 1987). In this case, the percent cover by the dominant coral Agaricia agaricites decreased significantly from 17 to 11 . (Agaricia agaricites comprised 47 to $91 \%$ of the live coral in the transects.)

Recovery is presumably faster if the dominant corals are fast-growing branching species which reproduce primarily through fragmentation (Highsmith 1982). Stoddart $(1963,1969,1974)$ estimated several decades for recovery of the British Honduras reef following Hurricane Hattie (1961), while Shinn (1972) reported recovery after only 5 yr on Florida reefs. The Florida reef sites were dominated by Acropora spp. Highsmith et al. (1980) reported that $46 \%$ of the Acropora palmata fragments they examined on the Belize barrier reef 4 mo after Hurricane Greta (1978) had survived, and stumps on bases of most colonies were healing. Eleven 
months after Hurricanes David and Frederic (1979), Rogers et al. (1982) found that $66 \%$ and $35 \%$ of the $A$. palmata branches at Buck Island and Tague Bay (St. Croix), respectively, were still alive. (Note, however, that Rogers et al. (1982) found high mortality of detached $A$. palmata fragments 13 mo after these storms, and Knowlton et al. $(1981,1990)$ found delayed mortality in fragments of Acropora cervicornis following Hurricane Allen in Jamaica.]

Because Montastrea annularis, a slow-growing species with low rates of recruitment (Bak \& Engel 1979), is the dominant coral at our study site off Yawzi Point, recovery will be comparatively slow. The percent cover by $M$. annularis decreased by about $35 \%$ as a result of Hurricane Hugo. Edmunds \& Witman (1991; this issue) recorded a decrease of $34 \%$ for $M$. annularis at a nearby reef in Great Lameshur Bay following the storm. Although cover by $M$. annularis was significantly reduced, this species is still by far the most abundant coral at our study site. The new substrate created by the storm may provide additional settling surfaces for other hard coral species such as Agaricia agaricites and Porites porites which have relatively high rates of recruitment (Bak \& Engel 1979). However, colonization, survival, and growth of coral recruits will only occur in the absence of intense competition from algae.

Our understanding of the recovery process on coral reefs is limited by our lack of knowledge of successional patterns on reefs. As Pearson (1981) notes, 'It is not clear what constitutes a climax community, how it might differ from one locality to another, or what timescale is involved', It is not clear if shallow or deep reef zones recover more quickly (Pearson 1981). Recovery could be faster in shallower zones because of higher light intensities, and/or more grazing pressure. However, Birkeland (1977) found that while coral recruits grew faster in shallower water, they survived better in deeper water. Presumably, shallower zones would usually be more affected by heavy seas and dislodgement of loose rubble and will exhibit greater changes in spatial arrangement (Bak \& Luckhurst 1980). Because the Yawzi Point reef is protected within Virgin Islands National Park, recovery can proceed in the absence of major disturbance from human beings. Coastal development will not be permitted. However, trap fishing is allowed in the park and does occur in the Lameshur Bays. The intensity of fishing has not been determined.

The new substrate exposed by mechanical breakage of coral skeletons during a storm is usually colonized by filamentous green algae within a few days, followed by the red algae Liagora spp. and other macroscopic species (Woodley et al. 1981, Rogers et al. 1982, Woodley 1989). The dramatic increase in macroscopic algal abundance (primarily Dictyota spp.) at the Yawzi Point reef following Hugo could have been a seasonal increase because algal cover rose again in November 1990. The profusion of algal growth could also have been a direct result of the storm, i.e. a response to the new substrate available for colonization, to nutrients associated with runoff during and a few days after the storm, or to reductions in grazing pressure.

It is likely that a combination of factors is responsible for the dramatic increases in algae noted after the hurricane and subsequent decreases. Monitoring of fish populations off Yawzi Point indicates that herbivorous fishes may initially have moved off the reef following Hurricane Hugo, reducing grazing pressure on the reef algae (Beets \& Friedlander 1990). Walsh (1983) has reported similar movement of fishes from shallow to deeper water after a severe storm in Hawaii. Visual census data show that the abundance of fishes declined off Yawzi Point following the hurricane and remained low for 3 mo afterwards. By March 1990, when macroscopic algal cover had declined in the transects, parrotfishes and surgeonfishes had significantly increased (Beets \& Friedlander 1990). Carpenter (1990a) notes that a reduction of herbivory allows macroalgae to outcompete algal turf and crustose species. Macroscopic algae dominated coral communities off St. Croix (Carpenter 1990a) and Jamaica (Hughes et al. 1987) following the Caribbean-wide mortality of the black sea urchin Diadema antillarum. Carpenter (1990b) reported that increased grazing by fishes at his St. Croix sites did not compensate for decreased grazing by sea urchins, and the percent cover and biomass of the algal community continued to rise. The subsequent reduction in cover by macroalgae noted at our study site in March 1990 could have been a reflection of renewed grazing, seasonal reduction in abundance, or the dislodging of algae by strong current or wave action. Many clumps of Dictyota within the transects were detached or only loosely attached to the substrate.

We do not know if grazing pressure in the Lameshur Bays has been reduced because of overfishing, a decrease in fishes at the site as a result of Hugo, or a decrease in the numbers of the black sea urchin Diadema antillarum during the Caribbean-wide epidemic (Lessios et al. 1984) or as a result of the hurricane (D. Levitan pers. comm.) D. antillarum are presently not abundant at the Yawzi Point study site.

Human activities before and after storms can influence not only the speed but also the nature of recovery. For example, extreme overfishing in Jamaica has reduced the populations of herbivorous fishes, resulting in algal smothering of small corals and algal encroachment on the periphery of larger colonies (Woodley 1989). An increase in algal biomass has also resulted from the mortality of the sea urchin Diadema antillarum 
(Hughes et al. 1987). This algal proliferation presumably could radically alter coral recruitment patterns. Hughes et al. (1987) observed dramatic declines in coral cover (up to $60 \%$ ) because of competition with algae.

Recovery will be delayed by natural processes such as additional storms, intense predation, algal overgrowth, and coral diseases, as well as activities such as dredging, destructive anchoring, boat groundings, and hillside clearing which accelerates runoff. Populations of the once-dominant reef-building coral Acropora cervicornis have failed to recover after destruction by Hurricane Allen in 1980 in spite of this species' fast growth rate because of a combination of factors, including predation and algal growth (Knowiton et al. 1981, Williams 1984, Hughes et al. 1987, Knowlton et al. 1990). Hurricane Gilbert smashed the Discovery Bay coral reef (Jamaica) 8 yr after the spectacular devastation of Hurricane Allen. Woodley (1989) reports that Gilbert returned the reef to conditions prevailing just after Allen. While damage was severe from Gilbert, it was less than it would have been if the previous storm had not occurred years earlier. For example, $97 \%$ of the Montastrea annularis colonies at $10 \mathrm{~m}$ which remained after Allen survived the onslaught of Gilbert.

\section{The Intermediate Disturbance Hypothesis}

Our research and other recent quantitative studies allow us to examine the effects of physical disturbance on coral reef ecosystems and to test the 'Intermediate Disturbance Hypothesis', the hypothesis that high diversity is a product of disequilibrium and occurs at moderate levels of disturbance (Grigg \& Maragos 1974 , Connell 1978). Grigg \& Maragos (1974) studied coral communities which had developed on submerged lava flows off Hawaii and found that diversity was highest at more exposed sites with low coral cover and lowest at sheltered (less disturbed) sites with high coral cover.

The effects of storms on hard coral diversity are complicated and sometimes counterintuitive. They vary with storm intensity, storm frequency, coral colony size and morphology, depth and zonation. Dollar (1982) studied 4 reef zones off Kona, Hawaii, during 'normal conditions' and after 2 storms, one moderate ('intermediate') and one severe. Coral diversity $\left(\mathrm{H}^{\prime}\right)$ for the reef as a whole increased after the moderate storm. However, the effects of the storm differed in the various zones, with diversity increasing in the zone monopolized by a single species and decreasing in the zone with highest evenness. However, an examination of the data presented for the individual transects within each zone show a large degree of variation. For example, in one zone, 3 of the 5 transects actually had the highest diversity after the severe storm.
The mean diversity of the zones Dollar (1982) studied ranged from near zero to only 0.973 , and 3 coral species accounted for $97 \%$ of all coral cover. Would the results have been similar for a more diverse reef?

Dollar (1982) states that infrequent, and unpredictable events that are intense enough to be equally destructive to all species, effectively wipe out the zonation pattern and return the entire reef to an early, low diversity, successional stage'. We suspect that few storms are this destructive; the patchy nature of storm damage makes equal destruction to all species unlikely. In fact, the mean coral diversity of 3 of the 4 zones Dollar studied (1982) was actually higher after the severe storm than prior to either of the 2 storms, i.e. under 'normal conditions', although diversity had decreased in 3 of 4 zones when compared to the patterns following the moderate storm. These data illustrate the importance of knowing the ecological history' of a site. The effects of the severe storm were influenced by the passage of a moderate storm $6 \mathrm{yr}$ earlier.

Diversity $\left(\mathrm{H}^{\prime}\right)$ increased in Jamaica following Hurricane Allen (1980) (Porter et al. 1981, Woodley et al. 1981) and in St. John following Tropical Storm Klaus (1984) (Rogers \& Zullo 1985) because the dominant coral species, Acropora cervicornis and Agaricia agaricites, respectively, suffered the greatest mortality. In contrast, diversity and evenness for the coral community off Yawzi Point did not decrease significantly although the dominant species, Montastrea annularis, was reduced significantly. Changes in mean percent total coral cover provided more information on storm effects than measures of diversity.

Interpretation and evaluation of storm responses in light of the intermediate disturbance hypothesis are complicated by wide differences in reef morphology, species composition, and zonation. Also, there is a need to define what constitutes severe and moderate disturbance. It should be noted that Connell (1978) discusses this hypothesis on the basis of species richness, not $\mathrm{H}^{\prime}$ which incorporates species richness and evenness (relative abundance). Number of species will not always respond in the same manner as overall diversity $\left(\mathrm{H}^{\prime}\right)$.

Analyses of the effects of disturbance on coral reefs usually focus on the hard corals. A complete understanding of ecosystem response to storms would require information on the myriad other organisms associated with coral reefs. The effects of disturbance on these organisms could differ greatly from the effects on the hard corals (see Woodley et al. 1981). For example, Walsh (1983) studied the fish community associated with reefs off the Kona coast of Hawaii before and after the same severe storm described by Dollar (1982). He noted that in spite of significant reductions in struc- 
tural relief (shelter) the fish community was equally or more diverse than before the storm.

Current programs establishing long-term monitoring of coral reefs should start to enable scientists to differentiate long-term fluctuations on the reefs from responses to anthropogenic and natural disturbances (Brown \& Howard 1985). As Hatcher et al. (1989) point out, 'The non-equilibrial nature of coral reef communities makes it difficult to determine "standard" reef conditions against which to evaluate impacts...' Major progress in understanding recovery processes will require more information not only on hard coral populations but also on gorgonians, anemones, sponges, fishes, and the other organisms which contribute to the fantastic diversity of coral reef systems.

Acknowledgements. We would like to express our appreciation to Jim Beets and Alan. Friedlander for assistance with the statistical analyses and for valuable comments on the manuscript. Betsy Gladfelter, Pete Edmunds, and 2 anonymous reviewers made several very useful suggestions for this paper We also thank Sean Baker, Alan Friedlander, and Lisa Muehlstein for their help with the field work. This work was funded by the National Park Service under its Coral Reef Assessment Program

\section{LITERATURE CITED}

Avila, L. A. (1990). Atlantic tropical systems of 1989. Mon. Weather Rev. 118: 1178-1185

Bak, R. P. M., Engel, M. S. (1979). Distribution, abundance, and survival of juvenile hermatypic corals (Scleractinia) and the importance of life history strategies in the parent coral community. Mar Biol. 54: 341-352

Bak, R. P. M., Luckhurst, B. E. (1980). Constancy and change in coral reefs habitats along depth gradients at Curaçao. Oecologia 47. 145-155

Beets, J., Friedlander, A. (1990). Long-term monitoring of fisheries in the Virgin Islands National Park: impact of Hurricane Hugo. National Park Service Coral Reef Assessment Program Interim Report, p. 1-23

Birktland, C. (1977). The importance of rate of biomass accumulation in early successional stages of benthic communities to the survival of coral recruits. Proc. 3rd int Coral Reef Congr. 1: 15-21

Brock, R. E. (1979). An experimental study on the effects of grazing by parrotfishes and role of refuges in benthic community structure. Mar. Biol. 51 381-388

Brown, B. E., Howard, L. S. (1985). Assessing the effects of 'stress' on reef corals. Adv. mar. Biol. 22: 1-63

Bythell, J. C., Gladfelter, E. H., Lewis, S. K., Woodbury, M. (1991). Impact of Hurricane Hugo at Buck Island Reef National Monument, St. Croix, U.S. Virgin Islands. II. Organism. level processes and their potential effect on the population dynamics of three dominant reef-building corals. Chap. 4. Ecological studies of Buck Island Reef National Monument, St. Croix, U.S. Virgin Islands: a quantitative assessment of selected components of the coral reef ecosystem and establishment of long-term monitoring sites. Part 1. National Park Service Coral Reef Assessment Program Report, p. 1-28

Carpenter, R. C. (1990a). Mass mortality of Diadema antil- larum. I. Long-term effects on sea urchin populationdynamics and coral reef algal communities. Mar. Biol. 104 $67-77$

Carpenter, R. C. (1990b). Mass mortality of Diadema antillarum. II. Effects on population densities and grazing intensity of parrotfishes and surgeonfishes. Mar. Biol. 104: 79-86

Case, R. A., Mayfield, M. (1990). Annual summaries. Atlantic hurricane season of 1989. Mon. Weather Rev. 118: $1165-1177$

Connell, J. H. (1973). Population ecology of reef-building corals. In: Jones, O. A., Endean, R. (eds.) Biology and geology of coral reefs, Vol. 2. Academic Press, London, p. $205-245$

Connell, J. H. (1976). Competitive interactions and the species diversity of corals. In: Mackie, G. O. (ed.) Coelenterate ecology and behavior. Plenum, New York, p. 51-58

Connell, J. H. (1978). Diversity in tropical rain forests and coral reefs. Science 199: 1302-1310

Dollar, S. J. (1982). Wave stress and coral community structure in Hawaii. Coral Reefs 1: 71-81

Edmunds, P. J., Witman, J. D. (1991). Effect of Hurricane Hugo on the primary framework of rcefs along the south shore of St. John, US Virgin lsianids. Mar. Ecol. Prog. Ser. 78 201-204

Endean, R. (1976). Destruction and recovery of coral reef communities. In: Jones, O. A., Endean, R. (eds.) Biology and geology of coral reefs, Vol. 3. Academic Press, London, p. 215-254

Gladfelter, E. H., Bythell, J. C. Archer, S., Lewis, S. K., Woodbury, M. (1991). Impact of Hurricane Hugo at Buck Island Reef National Monument, St. Croix, U.S. Virgin Islands: I. Effect on coral community structure and diversity relative to changes in the system since 1976. Chap. 3. Ecological studies of Buck Island Reef National Monument, St. Croix, U.S. Virgin Islands: a quantitative assessment of selected components of the coral reef ecosystem and establishment of long-term monitoring sites. Part. 1 National Park Service Coral Reef Assessment Program Report, p. 1-37

Glynn, P. W., Almodovar, L. R., Gonzalez, J. (1964). Effects of I lurricane Edith on marine life in La Parguera, Puerto Rico. Carib. J. Sci. 4: 335-345

Gray, W M. (1990). Strong association between west African rainfall and U S. landfall of intense hurricanes. Science 2 . $1251-1256$

Grigg, R. W., Maragos, J. E. (1974). Recolonization of hermatypic corals on submerged lava flows in Hawaii. Ecology 55 : 387-395

Hatcher, B. G., Johannes, R. E., Robertson, A. I. (1989). Review of research relevant to the conservation of shallow tropical marne ecosystems. Oceanogr. mar Biol. Ann. Rev. 27: $337-414$

Highsmith, R C (1982). Reproduction by fragmentation in corals. Mar Ecol. Prog. Ser. 7. 207-226

Highsmuth, R. C., Riggs, A. C., D'Antonio, C. M. (1.980). Survival of hurricane-generated coral fragments and a disturbance model of reef calcification/growth rates. Oecologia 46: $322-329$

Hughes, T P., Reed, D. C., Boyle, M.-J. (1987). Herbivory on coral reefs: community structure following mass mortalıties of sea urchins. J exp. mar. Biol. Ecol. 113: 39-59

Kjerfve, B., Magill, K. E., Porter, J. W., Woodley, J. D. (1986). Hindcasting of hurricane characteristics and observed storm damage on a fringing reef, Jamaica, West Indies. J. mar. Res. 44: 119-148

Knowlton, N., Lang, J. C., Rooney, M. C., Clifford, P. (1981). Evidence for delayed mortality in hurricane-damaged Jamaican staghorn corals. Nature, Lond 294: 251-252 
Knowlton, N., Lang, J. C., Keller, B. D. (1990). Case study of natural population collapse: post-hurricane predation on Jamaican staghorn corals. Smithson. Contr. mar Sci. 31, $25 \mathrm{pp}$.

Lessios, H. A., Robertson, D. R., Cubit, J. D. (1984). Spread of Diadema mass mortality through the Caribbean. Science 226: $335-337$

Loya, Y (1972). Community structure and species diversity of hermatypic corals at Eilat, Red Sea. Mar. Biol. 13: 100-123

Loya, Y (1976). Recolonization of Red Sea corals affected by natural catastrophes and man-made perturbations. Ecology 57: 278-289

Loya, Y., Slobodkin, L. B. (1971). The coral reefs of Eilat (Gulf to Eilat, Red Sea). Symp. Zool. Soc. Lond. 28: 117-139

Luckhurst, B. E., Luckhurst, K. (1978). Analysis of the influence of substrate variables on coral reef fish communities. Mar Biol. 49: 317-323

Miller, R. (1985). Multiple comparisons. In: Kotz, S, Johnson, N. L. (eds.) Encyclopedia of statistical sciences, Vol. 5. Wiley, New York, p. 679-689

Neumann, C. J., Cry, G. W., Casso, E. L., Jarvinene, B. R. (1978). (Revised annually). Tropical cyclones of the North Atlantic Ocean, 1871-1980. National Climatic Center, Asheville, N.C., p. 1-174

Pearson, R. G. (1981). Recovery and recolonization of coral reefs. Mar Ecol. Prog. Ser. 4: 105-122

Pielou, E. C. (1966). The measurement of diversity in different types of biological collections. J. theor. Biol. 13: 131-144

Pielou, E. C. (1977). Mathematical ecology. John Wiley \& Sons, New York

Porter, J. W. (1972). Patterns of species diversity in Caribbean reef corals. Ecology 53: 745-748

Porter, J. W., Woodley, J. D., Smith, G. J., Neigel, J. E., Battey, J. F., Dallmeyer, D. G. (1981). Population trends among Jamaican reef corals. Nature, Lond. 294: 249-250

Risk, M. J. (1972). Fish diversity on a coral reef in the Virgın Islands. Atoll Res. Bull. 153: 1-6

Rogers, C. S., Gilnack, M. Fitz, H. C., III. (1983). Monitoring of coral reefs with linear transects: a study of storm damage. J. exp. mar. Biol. Ecol. 66: 285-300

Rogers, C. S., Suchanek, T H., Pecora, F. A. (1982). Effects of Hurricanes David and Frederic (1979) on shallow Acropora

This article was presented by C. Birkeland, Guam palmata reef communities: St. Croix, U.S. Virgn Islands Bull. mar Sci. 32: 532-548

Rogers, C. S., Zullo, E. (1987). Initiation of a long-term monitoring program for coral reefs in the Virgin Islands National Park. Biosphere reserve research report no. 17 Virgin Islands Resource Management Cooperative/ National Park Service, p. 1-33

Shannon, C. E. Weaver, W. (1949). The mathematical theory of communication. University of Illinois Press, Urbana

Shinn, E. A. (1972). Coral reef recovery in Florida and in the Persian Gulf. Environmental Conservation Department, Shell Oil Co., Houston, p. 1-9

Sokal, R. R., Rohlf, F. J. (1969). Biometry. W. H. Freeman and Co., San Francisco

Stoddart, D. R. (1963). Effects of Hurricane Hattie on the British Honduras reefs and cays, October 30-31, 1961. Atoll Res. Bull. 95: 1-142

Stoddart, D. R. (1969). Post-hurricane changes on the British Honduras reefs and cays: re-survey of 1965. Atoll Res. Bull 131: $1-25$

Stoddart, D. R. (1974). Post-hurricane changes on the British Honduras reefs: re-survey of 1972. In: Cameron, A. M. et al. (eds.) Proc. Second International Symp. Coral Reefs, Great Barrier Reef Committee, Brisbane 2: 473-483

Walsh, W J. (1983). Stability of a coral reef fish community following a catastrophic storm. Coral Reefs 2: 49-63

Williams, A. H. (1984). The effects of Hurricane Allen on back reef populations of Discovery Bay, Jamaica. J. exp. mar. Biol. Ecol. 75: 233-243

Woodley, J. D. (1989). The effects of Hurricane Gilbert on coral reefs at Discovery Bay. Appendix 9. In: Bacon, P. (ed.) Assessment of the economic impacts of Hurricane Gilbert on coastal and marine resources in Jamaica. CEP Technical Report No. 4, UNEP Caribbean Environment Programme, Kingston

Woodley, J. D., Chornesky, E. A., Clifford, P. A., Jackson, J. B C., Kaufman, L. S., Knowlton, N., Lang, J. C., Pearson, M P. Porter, J. W., Rooney, M. C., Rylaarsdam, K. W., Tunnicliffe, V. J., Wahle, C. M., Wulff, J. L., Curtis, A. S. G., Dallmeyer, M. D., Jupp, B. P., Koehl, M. A. R., Niegel, J., Sides, E. M. (1981). Hurricane Allen's impact on Jamaican coral reefs. Science 214: 749-755

Manuscript first received: March 6, 1991

Revised version accepted: September 16, 1991 